\title{
PENGARUH SENAM TERHADAP KELUHAN MUSKULOSKELETAL PADA LANSIA
}

\author{
Rina Kurnia \\ Poltekkes Kemenkes Surakarta Jurusan Okupasi Terapi
}

\begin{abstract}
Background: The elderly group is a high risk group that experiences various health problems, especially degenerative diseases. Elderly people tend to experience a decrease in the musculoskeletal system. Decreases in the musculoskeletal system can cause disruption to physical mobility in the elderly. Methods: The purpose of this study was to determine the effect of gymnastic on musculoskeletal disorders. The study was quantitative research with experimental one group pre-test post-test design. It was conducted at the Posyandu in Nggaren, Pandeyan Village, Ngemplak, Boyolali. Sampling was done by total sampling technique with a total of 48 respondents. Analysis of data using Wilcoxon. Results: $p$-value $=0.001$ ( $p$ <0.005). Conclusion: there is an effect of gymnastic on musculoskeletal disorders in the elderly at the Posyandu in Nggaren, Pandeyan Village, Ngemplak, Boyolali.
\end{abstract}

Keywords: Gymnastic, Musculoskeletal Disorders, Elderly

\section{PENDAHULUAN}

Indonesia termasuk salah satu negara di Asia yang pertumbuhan Penduduk lansianya cepat. Sejak tahun 2000, Indonesia sudah memiliki lansia sebesar 14,4 juta penduduk $(7,18 \%$ dari jumlah penduduk) dan pada tahun 2020 diperkirakanakan berjumlah 28,8 juta $(11,34 \%)$. Hasil pendataan yang dilakukan pada tahun2007 ditemukan penduduk Lansia berjumlah 18,96 juta $(8,42 \%$ dari total penduduk) dengan komposisi perempuan $9,04 \%$ dan $7,80 \%$ laki laki (Badan Pusat Statistik, 2013).

Perubahan fisik pada lansia lebih banyak ditekankan pada penurunan atau berkurangnya fungsi alat indera dan sistem saraf mereka seperti penurunan jumlah sel dan cairan intra sel, sistem kardiovaskuler, sistem pernafasan, sistem gastrointestinal, sistem endokrin dan sistem musculoskeletal. Perubahanperubahan fisik yang nyata dapat dilihat membuat lansia merasa minder atau kurang percaya diri jika harus berinteraksi dengan lingkungannya (Santrock, 2002).

Lansia cenderung mengalami penurunan pada sistem muskuloskeletal. Penurunan pada sistem muskuloskeletal dapat mengakibatkan gangguan pada mobilitas fisik pada lansia (Taslim, 2001). Perubahan struktur fungsi fisik maupun mental akan mempengaruhi kemampuan seseorang untuk melakukan aktivitas (Ayu \& Warsito, 2012).

Beberapa penyebab keluhan muskuloskeletal adalah : (1) peregangan otot berlebihan, (2) aktifitas berulang, (3) sikap kerja tidak alamiah, (4) faktor penyebab sekunder (tekanan, getaran, mikroklimat), (5) penyebab kombinasi. Selain kelima faktor tersebut, beberapa ahli menjelaskan bahwa faktor individu seperti usia, jenis kelamin, kebiasaan merokok, aktifitas fisik, kekuatan fisik, dan ukuran tubuh juga dapat menjadi 
faktor resiko terjadinya keluhan muskuloskeletal (Tarwaka, 2011).

Keluhan muskuloskeletal pada umumnya memberikan gejala atau keluhan nyeri sehingga mengganggu aktivitas. Oleh karena itu, penanganan keluhan muskuloskeletal yang pertama kali dilakukan adalah untuk mengurangi nyeri atau gejala yang ditimbulkan (Martono, 2009). Penelitian Osteras et al (2009) didapatkan hasil bahwa pemberian terapi latihan medik menurunkan skala nyeri pada bahu. Berdasarkan hasil penelitian Bahman (2012) didapatkan bahwa skala nyeri lansia dengan arthritis setelah diberikan senam lansia secara teratur dapat berkurang secara signifikan. Serta berdasarkan penelitian Diniati et al, (2013) bahwa ada hubungan antara senam lansia dengan kekambuhan nyeri sendi pada lansia penderita arthritis.

Salah satu faktor yang diperkirakan mempengaruhi fungsi fisik adalah aktifitas fisik termasuk mobilitas (Yaffe et al., 2001). Senam bagi lansia didesain menggunakan prinsip gerakan penguluran (stretching) yang merupakan aktifitas fisik.

Berdasarkan latar belakang di atas maka dilakukan penelitian tentang pengaruh senam terhadap keluhan muskuloskeletal pada lansia di Posyandu Dusun Garen, Desa Pandeyan Ngemplak Boyolali.

\section{METODE PENELITIAN}

Penelitian ini adalah penelitian kuantitatif. Rancangan penelitian yang digunakan adalah experimental one group pre-test post-test design. Populasi dalam penelitian ini adalah lansia di Posyandu Dusun Nggaren Desa Pandeyan Kecamatan Ngemplak Kabupaten Boyolali. Teknik pengambilan sampel dengan total sampling. Jumlah sampel pada penelitian ini adalah 48 responden. Variabel independen dalam penelitian ini adalah senam, sedangkan variabel dependen dalam penelitian ini adalah keluhan muskuloskeletal.

Teknik pengumpulan data menggunakan data primer yang diperoleh langsung oleh peneliti dengan pengukuran langsung kepada sampel. Metode pengumpulan data dengan cara melakukan pengukuran dengan instrument penelitian Instrumen penelitian yang digunakan dalam penelitian ini adalah Nordic Body Map .

\section{HASIL PENELITIAN}

Tabel 1. Nilai Nordic Body Map (NBM) Sampel Penelitian Sebelum dan Sesudah Intervensi

\begin{tabular}{lcccc}
\hline \multirow{2}{*}{ Kategori } & \multicolumn{2}{c}{ NBM } & \multicolumn{2}{c}{ NBM } \\
& Sebelum intervensi & \multicolumn{2}{c}{ Sesudah Intervensi } \\
\hline \multirow{3}{*}{ Rendah } & $\mathrm{n}$ & $\%$ & $\mathrm{n}$ & $\%$ \\
\cline { 2 - 5 } Sedang & 8 & 16,7 & 12 & 25 \\
Tinggi & 35 & 72,9 & 35 & 72,9 \\
Jumlah & 5 & 10,4 & 1 & 2,1 \\
& 48 & 100 & 48 & 100 \\
\hline
\end{tabular}

Hasil dari tabel 1, dapat dijelaskan bahwa terdapat perbedaan presentase nilai Nordic Body Map sebelum dan sesudah intervensi pada kategori rendah16,7\% menjadi $25 \%$ dan pada kategori tinggi 10,4 $\%$ menjadi $2,1 \%$.

Tabel 2. Hasil Analisis Uji Komparatif Menggunakan Wilcoxon Terhadap Keluhan Muskuloskeletal Sebelum dan Sesudah Intervensi

\begin{tabular}{lc}
\hline Data & $\begin{array}{c}\text { Nilai Signifikansi } \\
\text { (p value) }\end{array}$ \\
\hline $\begin{array}{l}\text { NBM Pre }-N B M \\
\text { Post }\end{array}$ & 0,001 \\
\hline
\end{tabular}

Dari tabel 2 dapat dijelaskan bahwa dengan menggunakan derajat kesalahan $\alpha$ $0,05(95 \%)$ diperoleh nilai $\mathrm{p}<0,05$, 
sehingga dapat dinyatakan bahwa terdapat perbedaan signifikan antara nilai pre test NBM dengan nilai post test NBM. Berdasarkan data tersebut dapat diambil kesimpulan bahwa senam berpengaruh terhadap penurunan keluhan muskuloskeletal lansia di Dusun Nggaren, pandeyan, Ngemplak, Boyolali

\section{PEMBAHASAN}

Senam dalam penelitian ini didesain dengan memberikan aktivitas fisik menggunakan prinsip gerakan penguluran otot (stretching) dimulai dari bagian tubuh atas (kepala) sampai dengan tubuh bagian bawah (kaki) dan diakhiri dengan gerakan pernapasan dengan total durasi 15 menit/sesi. Dampak dari melakukan senam ini dapat dirasakan oleh responden, melalui wawancara dengan beberapa responden mereka menyampaikan bahwa badannya merasa lebih enak, jarang merasakan pegal-pegal. Hasil wawancara ini juga didukung dengan hasil uji wilcoxon dengan nilai signifikansi 0,001 yang berarti senam berpengaruh terhadap keluhan muskuloskeletal yang dialami oleh responden. Senam memberikan dampak positif terhadap penurunan keluhan muskuloskeletal.

Pemberian stretching dapat mengurangi spasme karena proprioceptor otot atau muscle spindle yang teraktivasi saat stretching terjadi. Muscle spindle bertugas untuk mengatur sinyal ke otak tentang perubahan panjang otot dan perubahan tonus yang mendadak dan berlebihan. Jika ada perubahan tonus otot yang mendadak dan berlebihan, maka muscle spindle akan mengirimkan sinyal ke otak untuk membuat otot tersebut berkontraksi sebagai bentuk pertahanan dan mencegah cedera. Dengan kontraksi otot yang minimal pada saat stretching, akan memudahkan muscle fibers untuk memanjang dan spasme otot dapat berkurang (Appleton, 1998; Costa\& Viera, 2008).

Menurut Cameron (1999), bahwa pemberian stretching juga dapat merangsang serabut saraf berpenampang tebal (A alpha dan A beta) sehingga mampu menutup gerbang kontrol nyeri. Mekanisme stretching termasuk dalam kategori stimulasi mekanik yang dapat mengaktivasi fungsi serabut saraf berpenampang tebal non-nociceptif (A alpha dan A beta) dan menutup gerbang kontrol sehingga nyeri yang dibawa serabut saraf berpenampang tipis (A delta dan C) tidak dapat diteruskan ke otak.

Menurut Costa \& Vieira (2008), pemberian stretching dapat memutus lingkaran spasme-nyeri-spasme karena pekerjaan dengan posisi statis yang membuat otot-otot penegak tubuh berkontraksi isometrik secara terus menerus sehingga terjadi ischemia. Ischemia pada otot dapat berujung pada keluhan nyeri sebagai tanda dan peringatan dari tubuh karena ada jaringan yang cedera bahkan menuju kerusakan. Saat dilakukan stretching, maka ischemia pada otot yang spasme dapat berkurang melalui efek meningkatnya sirkulasi darah pada otot tersebut. Dengan ischemia berkurang, maka secara otomatis sinyal nyeri karena kerusakan jaringan juga berkurang.

Kontraksi dinamik pada otot-otot yang terjadi saat melaksanakan senam menyebabkan lebih banyak darah mengalir ke otot, sehingga pasokan oksigen dan nutrisi yang dibutuhkan untuk proses metabolisme dapat dipenuhi secara efektif. Melakukan senam berarti merubah posisi tubuh statis menjadi lebih dinamis. Hal ini dapat menstimulasi kelancaran 
proses metabolisme dalam tubuh, sehingga penimbunan hasil metabolisme otot (asam laktat dan CO2) dapat diminimalisir.

\section{KESIMPULAN DAN SARAN}

Senam berpengaruh terhadap keluhan muskuloskeletal lansia di Posyandu Dusun Nggaren Desa Pandeyan Kecamatan Ngemplak Kabupaten Boyolali.

Penelitian dengan topik serupa disarankan untuk menggunakan instrumen yang lebih objektif untuk menilai keluhan muskuloskeletal.

\section{DAFTAR RUJUKAN}

Appleton., Michael., 1998. Stretch Physiology. Diakses pada 10 Agustus 2012.

Dari http://www.ifafitness.com/stretch2.ht $\mathrm{m}$

Ayu, A.A \& Warsito, B.E. 2012. Pemberian Intervensi Senam Lansia denganNyeri Lutut. Jurnal Nursing Studies. Vol : 1, No : 1

Badan Pusat Statistik, 2013. Proyeksi Penduduk Indonesia. Jakarta : Badan Pusat Statistik

Brahman. 2012. Pengaruh Senam Lansia Terhadap Skala Nyeri Pada Penderita Arthritis

Cameron., Michele.,1999. Physical Agents in Rehabilitation; W.B.Saunders company, Philadelphia.

Costa \& Vieira., 2008. Stretching to reduce work related musculoskeletal disorders; journal rehabilitation med 2008, (Internet). Diakses pada 10 Agustus 2012. Dari http://www.occmed.oxfordjournals.or g.
Departemen Kesehatan Republik Indonesia. 2006. Profil Kesehatan 2005. Jakarta.

Diniati, S.R., Rihiantoro, T. \& Astuti, T. 2013. Senam Lansia dan Kekambuhan Nyeri Sendi pada Lansia penderita Arthritis. Jurnal Keperawatan. Vol: IX, No: 2

Martono, H. 2009. Buku Ajar BoedhiDarmojo Geriatri Ilmu Kesehatan Usia Lanjut. Jakarta: Balai Penerbit Fakultas Kedokteran Universitas Indonesia

Santrock, J.W. 2002. Life-Span Development: Perkembangan Masa Hidup (edisi kelima). Jakarta: Erlangga

Taslim, H. 2001. Gangguan Muskuloskeletal pada Usia Lanjut. Diakses pada 8 Desember 2016. Dari http://www.tempo.co.id/medika/arsip/ 072001/pus-1.html.

Tarwaka., 2011. Ergonomi Industri. Dasar-dasar pengetahuan ergonomi dan aplikasi di tempat kerja. Harapan Press, Solo.

Yaffe, K., Lindquist, K., Penninx, B.W. 1996. Inflammatory markers and cognition in well-functioning AfricanAmerican and white elders. Neurology 2003: 61 76-8 